\title{
Responsible Water Reuse Needs an Interdisciplinary Approach to Balance Risks and Benefits
}

\author{
Milou M. L. Dingemans ${ }^{1, * \mathbb{C}}$, Patrick W. M. H. Smeets ${ }^{1}$, Gertjan Medema ${ }^{1,2}$, Jos Frijns ${ }^{1}{ }^{1}$, \\ Klaasjan J. Raat ${ }^{1}$, Annemarie P. van Wezel $^{3}$ and Ruud P. Bartholomeus $1,4, *$ D \\ 1 KWR Water Research Institute, 3430 BB Nieuwegein, The Netherlands; \\ patrick.smeets@kwrwater.nl (P.W.M.H.S.); gertjan.medema@kwrwater.nl (G.M.); jos.frijns@kwrwater.nl (J.F.); \\ klaasjan.raat@kwrwater.nl (K.J.R.) \\ 2 Department of Water Management, Faculty of Civil Engineering \& Geosciences, Delft University of \\ Technology, 2600 GA Delft, The Netherlands \\ 3 Institute for Biodiversity and Ecosystem Dynamics, University of Amsterdam, 1012 WX Amsterdam, \\ The Netherlands; a.p.vanwezel@uva.nl \\ 4 Soil Physics and Land Management Group, Wageningen University, 6708 PB Wageningen, The Netherlands \\ * Correspondence: milou.dingemans@kwrwater.nl (M.M.L.D.); ruud.bartholomeus@kwrwater.nl (R.P.B.)
}

Received: 20 March 2020; Accepted: 24 April 2020; Published: 29 April 2020

Abstract: Freshwater is a precious resource, and shortages can lead to water stress, impacting agriculture, industry, and other sectors. Wastewater reuse is increasingly considered as an opportunity to meet the freshwater demand. Legislative frameworks are under development to support the responsible reuse of wastewater, i.e., to balance benefits and risks. In an evaluation of the proposed European regulation for water reuse, we concluded that the proposed regulation is not practically feasible, as the water provider alone is responsible for the risk assessment and management, even beyond their span of control. The required knowledge and resources are extensive. Therefore, without clear guidance for implementation, the regulation would hinder implementation of reuse programs. As a consequence, the current practice of uncontrolled, unintentional, and indirect reuse continues, including related risks and inefficiency. Therefore, we provide an outline of the interdisciplinary approach required to design and achieve safe, responsible water reuse. Responsible water reuse requires knowledge of water demand and availability, quality and health, technology, and governance for the various types of application. Through this paper we want to provide a starting point for an interdisciplinary agenda to compile and generate knowledge (databases), approaches, guidelines, case examples, codes of practice, and legislation to help bring responsible water reuse into practice.

Keywords: water reuse; water quality; water availability; governance

\section{Introduction}

Freshwater is a precious resource, and shortages can lead to water stress impacting agriculture, industry and other sectors [1]. To reduce this, treated municipal (domestic) or industrial wastewater is increasingly considered as a freshwater resource. By wastewater reuse, the pressure on water resources can be reduced, which fits within the circular economy objectives [2]. However, water should only be reused in a responsible, sustainable manner, i.e., if no unacceptable additional risks for human health and the environment are introduced beyond current water sources. The main challenge for achieving such responsible water reuse is that there is considerable variation in (potential) risks and hazards, related to differences in water sources, application, and type of water treatment methods, and thus in water quality, and the use, practice, or method of application [3-10].

Applications of wastewater reuse in Europe include reuse of municipal wastewater for drinking water (e.g., Torrelee, BE [11]), as cooling water in industry (e.g., Tarragona, ES [12]) and for agricultural 
irrigation (e.g., Braunschweig, DE; Clermont-Ferrand, FR; Puglia, IT [13-15]), and of wastewater from the food industry for irrigation in agriculture (Lieshout, NL [16]) and horticulture (Dinteloord, NL [17]).

The EU's blueprint to safeguard Europe's water resources, stresses the need to use treated wastewater as a water resource for irrigation [3,18]. The Water Framework Directive and the Urban Wastewater Treatment Directive provide requirements for treatment of wastewater. For effluent reuse, however, the EU's blueprint identifies a lack of common standards, which led to a risk management framework by the Joint Research Centre to establish minimum quality requirements for water reuse in agriculture [19].

At current, there is no explicit EU regulation with regard to irrigation water. However, the proposed EU regulation for direct reuse of domestic wastewater for irrigation [20] has very recently been adopted by the EU Council and awaits adoption by the European Parliament [21]. It includes harmonized minimum quality requirements and risk management practices, as well as specific processes related to permits and obligations on the sharing of information on reuse. The proposed EU regulation for the direct reuse of domestic wastewater for irrigation asks for a detailed understanding of the benefits and risks of reuse for agricultural practices for each reuse program. This proposed regulation states that a water reuse risk management plan (WRRMP) is required for reclamation sites, to manage microbial and chemical risks in a proactive manner. Minimum quality requirements are proposed for different types of agricultural reuse, depending on crop category and irrigation method. Additional water quality requirements that are relevant to the specific reuse program should be added based on the WRRMP.

Earlier evaluations by independent experts [22] concluded that although many important elements are included in the proposed water quality requirements, several key aspects were inadequately addressed - in particular contaminants of emerging concern, spread of antibiotic resistance, disinfection by-products, and the potential of effect-based bioanalytical tools-and that the selection of minimum quality requirements is unclear. In this paper, the different aspects that should be considered in every water reuse case are addressed, i.e., water demand and availability, water quality (health and safety), treatment technology and governance (policy and regulations, economics, stakeholder participation and public acceptance) (Figure 1). The proposed EU guidelines for the reuse of domestic wastewater for irrigation and the WRRMP were critically reviewed with respect to practical feasibility for a specific water reuse case in the Netherlands [23]. This led to the identification of knowledge requirements for responsible water reuse. This paper provides an outlook on how the proposed regulations could be improved to encourage innovation in technically achieving, managing, monitoring, and regulating responsible water reuse.

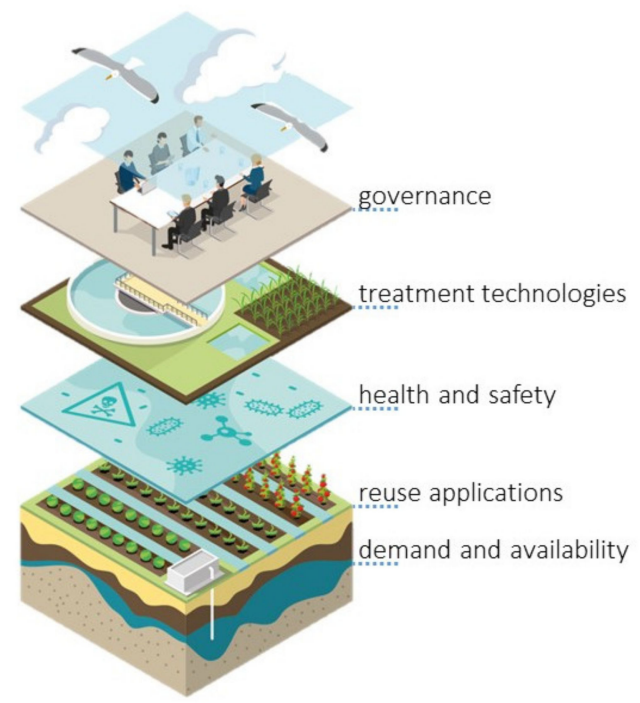

Figure 1. Different disciplines are needed for the practice of responsible water reuse. 


\section{Water Demand and Availability and Reuse Applications}

The most common freshwater sources are groundwater and surface water, often perceived as natural waters [24,25]. However, wastewater is already often indirectly (de facto) reused in agriculture, by irrigating with surface water in which treated domestic wastewater is discharged and diluted [26]. For several regions in Europe with agricultural irrigation the impact of wastewater effluent on irrigation water quality has been estimated to be significant [24]. Globally, it has been estimated that about $65 \%$ of irrigated croplands downstream of urban areas were located in catchments affected by urban wastewater flows [27]. The main drivers for the intentional reuse of effluent are declining groundwater levels and prolonged droughts [28]. Periods of drought in Europe, even in areas with an annual rainfall excess, have led to ad hoc use of treated wastewater for irrigation without adequate risk evaluations. Aquifer recharge or subsurface water storage to prevent or reduce salinization also creates demand for (reclaimed) freshwater [29].

Quantitatively, the reuse of domestic wastewater for irrigation has high potential to play an important role in water resource management. For direct water reuse, wastewater needs to be treated to such an extent that it is suitable for irrigation. Such intentional reuse offers better control and management possibilities than currently practiced de facto reuse. There is a lack of knowledge on the required water quality for safe use in agriculture, especially with respect to emerging compounds. Innovative treatment processes need to be applied to achieve this quality reliably, affordably, and sustainably. Since the demand is generally highest when there is least water available, concepts for underground buffering need to be developed. These in turn require sufficient water quality, but also may improve water quality [30,31]. Smart combinations of various reuse applications with varying demands will increase flexibility of the system, but require innovative business models to manage shared water resources. The proposed EU regulation for reuse is limited to direct reuse of treated domestic wastewater for irrigation. Therefore, it only applies to a selection of potential water reuse applications and is missing an integrated approach. The regulation asks for a detailed understanding of benefits and risks of reuse for agricultural practices. If a water provider does not have the specific expertise and realises that the required monitoring will be costly, the proposed regulation might discourage intended reuse and thus unintendedly stimulate an increase of indirect de facto reuse.

\section{Health and Safety including Water Treatment}

Current wastewater and sanitation systems were designed to efficiently remove wastewater from the home and release it into the environment to prevent contact with humans. A hazard related to wastewater reuse is that it may bring the contaminants from wastewater back to the living environment. Irrigation with treated wastewater may introduce pathogens and chemicals in the soil and to the plants, some of which may affect human health by transfer through the food chain, or via contamination through the air, surface water, or groundwater. Human health risks due to the presence of pathogens or chemicals can vary widely between cases of water reuse for irrigation, depending on the type of wastewater, land use, soil type, type of irrigation, exposure scenarios, and the hydrological conditions at the irrigation site [32]. Conventional wastewater treatment processes were not designed to remove pathogens and emerging contaminants [33]. Additional and innovative water treatment technologies based on sorption, oxidation and size exclusion principles, will thus be needed to produce fit-for-purpose water efficiently [34]. Recent activities to collect all knowledge on the removal of a wide variety of pathogens and (emerging) contaminants by common and advanced treatment technologies, such as activated carbon, the use of ozone and UV with or without $\mathrm{H}_{2} \mathrm{O}_{2}$, nanofiltration, and reverse osmosis, actually shows that knowledge is available but scattered, and continuously growing and expanding to new contaminants [34,35]. Also, different exposure routes and their respective relevance differ per situation and depend on type of irrigation, type of crop, and environmental fate of chemicals present in the reclaimed water in the soil. In each water reuse case, the following questions on water quality need to be addressed: Which risks related to the presence of pathogens or chemicals are relevant in this particular case and what water treatment technologies are effective? 
Pathogens in domestic wastewater include bacteria, viruses, protozoa and helminths. These are mostly enteric pathogens causing gastrointestinal disease that enter the wastewater by excretion from infected persons. Pathogens are currently not monitored in wastewater, so what is known about the presence of common and rare pathogens in various wastewater types is coming from research and is scattered [36]. Real-time quantitative polymerase chain reaction (PCR) analyses could serve as a relatively simple and cheap screening tool for pathogens in wastewater [37], although it needs to be considered that these methods cannot make a distinction between DNA from living or dead pathogens and thus could result in false positives. Viruses, bacteria, and parasites are only removed or inactivated to a limited extent in conventional (activated sludge and sedimentation) wastewater treatment processes [36]. So, for many reuse applications in agriculture, microbial safety requirements will require additional treatment or other risk management actions. In the proposed EU regulation for reuse of domestic wastewater for irrigation, minimum requirements are set only for the microbial parameters Escherichia coli (E. coli), Legionella spp. and helminth eggs, and several technical minimum requirements are also associated to microbial safety. Choosing E. coli as the general indicator to evaluate whether a reuse system is capable of producing water that is safe for the different irrigation purposes could result in a false sense of safety, as $E$. coli is very sensitive to disinfection processes in comparison to other microbial hazards [38]. Reused wastewater will generally contain more organics which stimulates microbial growth including opportunistic pathogens like Legionella. The requirement for Legionella $s p p$. is only in greenhouses where there is a risk of aerosolization. This is potentially a high-risk setting for Legionella pneumophila, given water temperatures in these irrigation systems. However, several urban wastewater systems have been associated with Legionella pneumophila outbreaks [39-42], particularly linked with wastewater influenced by high organic/high temperature waste streams such as from breweries or paper mills, so inclusion of reuse systems based on these waters is warranted. In addition, the proposed monitoring of Legionella spp. includes many non-pathogenic Legionella species that can be abundant in water systems, while the vast majority of severe infections is due to Legionella pneumophila. Its management might even increase the risk as Legionella species live in competition in biofilms. Disturbing the biofilm by disinfection of Legionella spp. might actually allow Legionella pneumophila to proliferate in the new situation [43]. Setting the requirement specifically for Legionella pneumophila would thus be a better indicator of risk.

There is discussion about the significance of the water route for human exposure to antibiotic resistant bacteria, but it is clear that many types of antibiotic-resistant bacteria and genes are present in wastewater [44]. WHO has indicated that discharge and exposure via domestic wastewater should be kept as low as reasonably achievable $[45,46]$. To demonstrate this, it would be beneficial to provide guidance and select a reference for antibiotic resistance, such as extended-spectrum betalactamase (ESBL) E. coli, given that it is widespread and one of the resistant bacteria of concern present at relatively high concentrations with good methods available for enumeration in wastewater.

Risks of chemicals for human health or the environment depend on the hazardous properties of the concerned chemicals and the margin between safe exposure levels and the realistic exposure that is occurring [47]. Exposure levels can be monitored, but in a risk management scheme exposure levels may also be predicted to some degree based on (expected) levels in wastewater, treatment efficiency, distribution and degradation in water, soil and air, and absorbance in plants [32,48]. Wastewater presents a continually evolving composition of chemicals in complex mixtures depending on human activities. Humans can thus be exposed to chemicals in reclaimed water via different exposure routes, partly depending on (professional) activities of the exposed individuals. For persistent chemicals, concentrations in wastewater-irrigated soils may even slowly rise with each successive wastewater application [32,49].

No minimum requirements for chemicals are included in the proposed regulation, but these are to be determined for specific chemicals in specific settings based on the outcomes of the WRRMP. This plan refers to existing EU legislation on chemicals in food and the environment. A list of relevant chemicals to consider for the validation and performance monitoring of reclamation plants can be 
based on their known or expected presence in wastewater, legislative criteria for (ground) water, and food safety requirements for crops such as maximum residue levels. Minimum requirements for these chemicals at the point of compliance, such as the outlet of the reclamation plant, can be defined based on relevant exposure routes and realistic worst-case fate and transport processes of chemicals from the release via STP towards human and environmental exposure. Wastewater also contains nutrients that can be useful for crop production, such as nitrogen, phosphorus, potassium and organic matter [50]. Required concentrations of nutrients vary in different crop production stages and there are some associated health hazards (e.g., nitrate). Reclaimed water for irrigation may also negatively impact agricultural productivity, especially through salt content [51]. Limit concentrations of chemicals in reused wastewater are either based on crop requirements or on human or environmental health concerns. Relevant chemicals can be derived by integrating information on occurrence in wastewater and their risks including legislative food safety requirements. Following the proposed regulation, environmental monitoring systems of water reuse systems would need to include the whole water pathway, i.e., at the reclamation plant, at the point of use and further downstream in the environment. This generally exceeds the span of control of individual water providers or managers.

Indirect potable reuse through drinking water production from domestic and industrial wastewater impacted surface water has provided several decades of experience on monitoring and managing water quality risks. Due to increased knowledge on possible adverse effects and increased analytical possibilities, the number of chemical parameters included in monitoring programs of water utilities increased exponentially in the last decade [52]. In accordance with the European Drinking Water Directive [53], utilities aim at a tailored risk-based monitoring program and this approach is also applicable to water reuse applications. Risk-based monitoring programs can be designed based on knowledge of the chemical composition of the wastewater and effluent, vulnerability of receiving groundwater and potential exposure routes. It is expected that a risk-based monitoring workflow for water reuse for irrigation can be based on the available technologies currently in use for drinking water purposes $[47,54]$. These can be complemented with bioanalytical tools that give information on the integrated effect of mixtures of chemicals related to a specific health effect $[55,56]$. By referring to a list of EU legislations on microbial and chemical risks from which requirements and obligations are also to be taken into account, many additional water quality requirements are indirectly included in the proposed regulation. Guidance on which requirements from these legislations should be included in a WRRMP needs to be further developed. Practical case studies can provide insight in what monitoring is practical, feasible and meaningful.

Awareness of the number of chemicals emitted to the aquatic environment in wastewater has also resulted in increased attention for and exploration of the merits of additional post-treatment at wastewater treatment plants [57]. Additional biological and technological treatments, such as activated sludge, membrane bioreactors, moving bed biofilm reactors, and nature-based solutions such as constructed wetlands may also be used in water reuse applications to mitigate risks [58]. The relevance of a treatment technology to a specific reuse case can be evaluated based on reliable removal efficiency data. Recently developed relevance and reliability criteria support the selection of appropriate technologies [59].

\section{Governance}

While water scarcity urges the practice of water reuse, large variation in potential hazards and risks forces to ensure responsible water reuse. This gives rise to a particular challenge in governance. A precautionary option for water reuse for irrigation would be to set a standard list of requirements, focused on expected exposures via food crops. Concentrations in harvested crop, environment, and biota can be measured or estimated based on fate and behaviour of chemicals and pathogens after release from the water treatment site $[60,61]$. The introduction of related uncertainty/extrapolation factors may lead to relatively conservative water quality standards that will need to be met and therefore monitored. Location specific risk-based approaches, where hazards and risk management measures 
are prioritized on a case-by-case basis, are expected to be more applicable. This avoids overly stringent quality standards that could discourage the development of reuse schemes by imposing burdensome treatment and/or costly monitoring requirements [62]. However, to require each reuse system to conduct their own specific evaluation of all relevant contaminants, their toxicity and uncertainties would make the regulations very difficult to implement and harmonize between reuse systems and member states. Hence, this risk-based approach requires additional efforts to provide guidance on how to define the minimum set of requirements relevant to specific water reuse cases.

The WRRMP evaluation process can be supported by the development of a database of relevant hazard and safety levels and guidance material on the development of monitoring requirements. Existing risk management methods, databases and tools such as the AquaNES Quantitative Microbial Risk Assessment (QMRA) tool [35] may be useful in this regard, even if they were not developed specifically for water reuse cases. Another applicable method is the framework for risk-based monitoring of groundwater sources for drinking water production established in the joint research program of Dutch and Flemish drinking water companies [52]. Also, EFSA has developed a guidance for predicting environmental concentrations of plant protection products and their transformation products [63]. Although this was originally developed for exposure assessment for soil organisms, this may also be applied for the evaluation of water reuse risks on human health and the environment.

The heterogeneity of water reuse cases and risk management needs, stresses the value of a progressive and enabling regulatory regime [64]. For a mature governance arrangement, it is critical to engage stakeholders and pursue the normalization of water reuse in society. Ensuring long-term collaboration and engagement of stakeholders and customers is one of the key success factors in the development of water reuse schemes [62]. Building confidence and gaining trust through early consultation allows for a location specific approach that deals with uncertainty regarding risks and their perception. Involvement of stakeholders is also advocated by Goodwin and co-workers in a water reuse safety plan approach [65]. An important element in the engagement of stakeholders, in particular the general public, is the societal legitimation of water reuse [66]. The use of long-term narratives around the benefits of adopting water reuse and the recognition that de facto reuse is common practice could support public acceptance [67]. A clear explanation of risks and risk management can support public acceptance by applying the principles of risk communication [68]. Unfortunately, the WRRMP in the new EU regulation for direct reuse of domestic wastewater [20] does not include stakeholder engagement requirements. This is however critical, since this WRRMP points to risk management actions that are generally beyond the control of the water provider in reuse utilities.

The governance arrangement of water reuse cases needs to address economic aspects as well. An important factor hampering the development of water reuse is related to the total costs of treatment and of monitoring the reuse system as a whole [15,62]. For those cases in which reclaimed water is used for agricultural purposes, there will also be substantial costs associated with the conveyance system and delivery management for irrigation [15]. On the other hand, water reuse cases are often undervalued as the range of (environmental) benefits are not accounted for. Giannoccaro et al. [15] point out that also often transaction costs are not considered. The costs for water reuse treatment are incurred by different organisations (public or private water industry) than those organisations benefitting from the availability of reclaimed water (e.g., farmers). This is a general challenge for the transition to the circular economy in which a new distribution of societal values is needed that goes beyond a cost-benefit analysis of a particular (e.g., water) reuse case. The circular economy will require systematic changes in the whole value chain for water, benefitting the economic development of water reuse practices $[69,70]$.

\section{Feasibility of the Proposed Regulation for a Specific Water Reuse Case}

The practical feasibility of the proposed regulation was evaluated by going through the WRRMP key risk management tasks for a sub-surface irrigation (SSI) case (research pilot) using effluent of a sewage treatment plant (STP) at Haaksbergen, the Netherlands. In this SSI case, STP effluent is actively 
added to a controlled drainage system. Such systems allow to control groundwater levels and soil moisture conditions at an agricultural field [71]. By actively adding water, controlled drainage systems become infiltration systems, or sub-irrigation systems (SSI). SSI systems can supply STP effluent to crops while the soil is used as filter and buffer zone [3]. The research pilot in Haaksbergen runs since 2015 [72].

The proposed regulation focuses on risks for water quality and health, and not on the potential benefits, or the risks of the current situation (irrigation with surface water that receives domestic wastewater). As opportunities (benefits) are not considered and the proposed risk analysis is very extensive, it is not possible to find a balance and implement responsible water reuse with this currently proposed regulation. Some specific shortcomings were identified. (i) Roles and responsibilities of the different stakeholders are not clearly described. (ii) Although needed to assess potential risks, the operator likely does not have detailed information on and jurisdiction over the infrastructure from the point of release (effluent) to the point of use (irrigation). In the Haaksbergen case, irrigation takes place using an innovative subsurface system that reduces the risks from direct application of water on crops or through aerosols. However, the proposed regulation does not address subsurface irrigation and requires measurements and (environmental) monitoring which may be less relevant for this type of irrigation. (iii) In particular, for emerging chemicals and pathogens, site-specific information on their occurrence in this case study wastewater is not readily available. Also, their fate and behaviour in the soil and in crops that will be consumed by humans or cattle is unknown. Determining whether additional requirements are needed requires the operator to perform a risk assessment and compare the outcome to acceptable levels of risk or water quality. (iv) Without guidance it is an exhaustive effort to monitor all relevant exposure routes and, in practice is outside the influence of the operator, who nevertheless has this responsibility according to the proposed regulation. (v) There is no guidance on adequate validation monitoring, and this is needed to support operators and to harmonize validation monitoring.

The evaluation of the proposed guideline shed light on the challenges of the implementation of the guideline to promote responsible water reuse. It provides guidance for research agendas and needs to make practical implementation feasible. Using novel, innovative methods, feasible and uncomplicated monitoring strategies can be developed for analyses of effluent water quality at the point of release without the need to monitor (inaccessible) points of use. Rather than requesting extensive monitoring at each reuse site, decision-making tools and databases with information on environmental fate could be developed to identify whether a water reuse application may result in increased environmental exposure (soil, surface water and groundwater, crops) on or near the irrigation site, potentially resulting in risks for ecology or humans. Measuring or modelling site-specific exposure of humans, cattle, and the environment to compare to safe concentration is extensive and complex. Alternatively, national or river-basin specific risk assessments can, to some extent, be based on national concentrations of hazards in urban wastewater, efficacy of treatment processes and public health and environmental water quality standards $[47,48,59]$. This can be used to define a manageable set of indicator chemicals from different classes of use and with different physicochemical properties. Additional site-specific requirements may be derived by risk-based approaches. A database with acceptable risk levels or water qualities for different reuse purposes, and relevant preventive measures, would facilitate the implementation of the proposed regulations. Agriculture can benefit from treated wastewater as freshwater resource, and risks can be managed by precautionary regulations based on the most relevant exposure route. If needed, reuse can be limited to those applications with limited risk potential.

Ongoing research and innovation is already providing a basis for these goals with existing databases, novel analysis methods and innovative treatments. The EU regulation on minimum requirements for water reuse $[19,20]$ is part of a legislative framework that is under development in the EU to support responsible reuse of wastewater for irrigation purposes. Other legislative frameworks related to water reuse are being developed worldwide (Table 1) allowing international sharing of knowledge and experience. New contaminants and new treatment technologies will continue to 
emerge. An integrated research agenda in the field of water reuse will support the efficient acquirement of necessary knowledge and steer innovation in the needed direction. User-friendly tools need to be developed together with end users that encapsulate this knowledge and allow stakeholders to apply this also in a non-scientific environment.

Table 1. Overview of existing and developing legislative frameworks of water reuse for industry, agriculture, or drinking water.

ISO Guidelines 20426, 20468, 20469 (2018)
WHO Guidelines for the safe use of wastewater, excreta and greywater (2006, revision ongoing)
WHO's Guidance of potable reuse (2017)
USEPA Guidelines for water reuse (2012)
US and California's Title 22 (updated in 2015)
Colorado incorporated water reuse in regulatory framework (no other states or US federal rules)
Australian Guidelines for Water Recycling (2006)
Oman national guidelines for water reuse
NS federal regulation Food Safety Modernisation Act (2017) (relevant for crop irrigation in Latin America)
EU Minimum requirements for water reuse in agriculture (legislation in consultation phase)
United Arab Emirates develops legal framework for water reuse (feasibility studies ongoing)
Saudi Arabia restructured water-related organizations and ministries to clarify responsibilities

\section{Conclusions}

Wastewater reuse is increasingly considered as an opportunity to meet the freshwater demand. This means a shift of paradigm from "safe treatment and discharge of wastewater" to "transforming used water to fit-for-purpose water". The following questions need to be addressed. To what degree are pressures on freshwater sources reduced by exploitation of treated wastewater? Which risks related to the presence of pathogens or chemicals are relevant in this particular case, and how does this impact selection of suitable water treatment technologies? What is the relevant legislation to be complied? Who are the responsible authorities and stakeholders for each of the elements of a reuse program, and are they all sufficiently involved?

The minimum requirements for microbial and chemical hazards in the proposed EU regulation do not sufficiently cover relevant risks to protect human and environmental health. The water reuse risk management plan in the proposed EU regulation is an interdisciplinary and exhaustive task and the proposed approach is not practically feasible, because it is very complex and operator influence and proposed responsibilities do not match. To support responsible water reuse, the evaluation of water reuse cases requires expert knowledge on both the benefits and risks regarding water availability, quality, and governance. Databases (on hazards, risks, background exposures and preventive measures) are needed to consistently and efficiently develop scientific, expert, and practical knowledge. Guidance material and decision-making tools are needed to disseminate expert knowledge and support decision makers and stakeholders for responsible water reuse, i.e., to make expert knowledge available for risk managers and stakeholders.

Author Contributions: Conceptualization, M.M.L.D.; P.W.M.H.S.; G.M.; J.F.; A.P.v.W.; K.J.R. and R.P.B.; writing-original draft preparation, M.M.L.D.; G.M.; P.W.M.H.S. and J.F.; writing-review and editing, R.P.B.; K.J.R. and A.P.v.W. All authors have read and agreed to the published version of the manuscript.

Funding: This work was funded by the joint research program of Dutch and Flemish drinking water companies and the Dutch Government.

Acknowledgments: We thank the editor and three anonymous reviewers for their valuable comments on the manuscript.

Conflicts of Interest: The authors declare no conflicts of interest. The funders had no role in the design of the study; in the collection, analyses, or interpretation of data; in the writing of the manuscript, or in the decision to publish the results. 


\section{References}

1. European Commission (EC). Water Reuse. 2018. Available online: http://ec.europa.eu/environment/water/ reuse.htm (accessed on 9 March 2020).

2. Water Research Europe (WRE). Water Reuse Europe Review. 2018. Available online: https://www.waterreuse-europe.org/wp-content/uploads/2018/08/wre_review2018_final.pdf (accessed on 9 March 2020).

3. Narain, D.M.; Bartholomeus, R.P.; Dekker, S.C.; Van Wezel, A.P. Natural purification through soils: Risks and opportunities of sewage effluent reuse in sub-surface irrigation. Rev. Environ. Contam. Toxicol. 2020, in press.

4. Hamilton, A.J.; Stagnitti, F.; Xiong, X.; Kreidl, S.L.; Benke, K.K.; Maher, P. Wastewater irrigation: The state of play. Vadose Zone J. 2007, 6, 823-840. [CrossRef]

5. Deng, S.; Yan, X.; Zhu, Q.; Liao, C. The utilization of reclaimed water: Possible risks arising from waterborne contaminants. Environ. Pollut. 2019, 254, 113020. [CrossRef]

6. Akpor, O.; Otohinoyi, D.; Olaolu, D.; Aderiye, B. Pollutants in wastewater effluents: Impacts and remediation processes. Int. J. Environ. Res. Earth Sci. 2014, 3, 50-59.

7. Moazeni, M.; Nikaeen, M.; Hadi, M.; Moghim, S.; Mouhebat, L.; Hatamzadeh, M.; Hassanzadeh, A. Estimation of health risks caused by exposure to enteroviruses from agricultural application of wastewater effluents. Water Res. 2017, 125, 104-113. [CrossRef]

8. Hoogenboezem, W.; Ketelaars, H.; Medema, G.; Rijs, G.; Schijven, J. Cryptosporidium en Giardia: Voorkomen in Rioolwater, Mest en Oppervlaktewater Met Zwem-En Drinkwaterfunctie. RIWA/RIVM/KIWA Report. Available online: http://publicaties.minienm.nl/documenten/cryptosporidium-en-giardia-voorkomen-inrioolwater-mest-en-opper (accessed on 16 April 2020).

9. Sharma, M.; Handy, E.T.; East, C.L.; Kim, S.; Jiang, C.; Callahan, M.T.; Allard, S.M.; Micallef, S.; Craighead, S.; Anderson-Coughlin, B.; et al. Prevalence of Salmonella and Listeria monocytogenes in non-traditional irrigation waters in the Mid-Atlantic United States is affected by water type, season, and recovery method. PLoS ONE 2020, 15, e0229365. [CrossRef]

10. Panthi, S.; Sapkota, A.R.; Raspanti, G.; Allard, S.M.; Bui, A.; Craddock, H.A.; Murray, R.; Zhu, L.; East, C.; Handy, E.; et al. Pharmaceuticals, herbicides, and disinfectants in agricultural water sources. Environ. Res. 2019, 174, 1-8. [CrossRef]

11. Van Houtte, E.; Verbauwhede, J. Long-time membrane experience at Torreele's water re-use facility in Belgium. Desalin. Water Treat. 2013, 51, 4253-4262. [CrossRef]

12. Pintilie, L.; Torres, C.M.; Teodosiu, C.; Castells, F. Urban wastewater reclamation for industrial reuse: An LCA case study. J. Clean. Prod. 2016, 139, 1-14. [CrossRef]

13. Ternes, T.A.; Bonerz, M.; Herrmann, N.; Teiser, B.; Andersen, H.R. Irrigation of treated wastewater in Braunschweig, Germany: An option to remove pharmaceuticals and musk fragrances. Chemosphere 2007, 66, 894-904. [CrossRef]

14. Devaux, I.; Gerbaud, L.; Planchon, C.; Bontoux, J.; Glanddier, P.Y. Infectious risk associated with wastewater reuse: An epidemiological approach applied to the case of Clermont-Ferrand, France. Water Sci. Technol. 2001, 43, 53-60. [CrossRef] [PubMed]

15. Giannoccaro, G.; Arborea, S.; de Gennaro, B.C.; Iacobellis, V.; Piccinni, A.F. Assessing reclaimed urban wastewater for reuse in agriculture: Technical and economic concerns for Mediterranean Regions. Water 2019, 11, 1511. [CrossRef]

16. Bartholomeus, R.P.; Huijgevoort, M.H.J.; van Loon, A.H.; van den Eertwegh, G.A.P.H.; Raat, K.J. Matching agricultural freshwater supply and demand - using recycled water for subirrigation purposes. In Proceedings of the 12th IWA International Conference on Water Reclamation and Reuse, Berlin, Germany, 16-20 June 2019.

17. Zuurbier, K.G.; Smeets, P.W.M.H.; Roest, K.; van Vierssen, W. Use of Wastewater in Managed Aquifer Recharge for Agricultural and Drinking Purposes: The Dutch Experience. In Safe Use of Wastewater in Agriculture; Hettiarachchi, H., Ardakanian, R., Eds.; Springer: Cham, Switzerland, 2018.

18. European Commission (EC). A Blueprint to Safeguard Europe's Water Resources. 2012. Available online: https://eur-lex.europa.eu/legal-content/EN/TXT/PDF/?uri=CELEX:52012DC0673 (accessed on 16 April 2020).

19. Alcalde-Sanz, L.; Gawlik, B.M. Minimum Quality Requirements for Water Reuse in Agricultural Irrigation and Aquifer Recharge-Towards a Legal Instrument on Water Reuse at EU Level; EUR 28962 EN, Publications Office of the European Union: Luxembourg, 2017. 
20. European Commission (EC). Proposal for a Regulation of the European Parliament and of the Council on Minimum Requirements for Water Reuse. 2018. Available online: https://ec.europa.eu/environment/water/ pdf/water_reuse_regulation.pdf (accessed on 9 March 2020).

21. European Council. Water Reuse for Agricultural Irrigation: Council Adopts New Rules. Available online: https://www.consilium.europa.eu/en/press/press-releases/2020/04/07/water-reuse-for-agriculturalirrigation-council-adopts-new-rules (accessed on 16 April 2020).

22. Rizzo, L.; Krätke, R.; Linders, J.; Scott, M.; Vighi, M.; de Voogt, P. Proposed EU minimum quality requirements for water reuse in agricultural irrigation and aquifer recharge: SCHEER scientific advice. Curr. Opin. Environ. Sci. Health 2018, 2, 7-11. [CrossRef]

23. Dingemans, M.M.L.; Bartholomeus, R.P.; Medema, G.J. Evaluation of the Proposed EU Regulation on Minimum Requirements for Water Reuse for Irrigation. KWR Report. 2018. Available online: https: //library.kwrwater.nl/publication/56467244/ (accessed on 9 March 2020).

24. Drewes, J.E.; Hübner, U.; Zhiteneva, V.; Karakurt, S. Characterization of Unplanned Water Reuse in the EU; Publications Office of the European Union: Luxembourg, 2017.

25. Siebert, S.; Burke, J.; Faures, J.M.; Frenken, K.; Hoogeveen, J.; Döll, P.; Portmann, F.T. Groundwater use for irrigation-A global inventory. Hydrol. Earth Syst. Sci. 2010, 14, 1863-1880. [CrossRef]

26. Beard, J.E.; Bierkens, M.F.P.; Bartholomeus, R.P. Following the Water: Characterising de facto Wastewater Reuse in Agriculture in the Netherlands. Sustainability 2019, 11, 5936. [CrossRef]

27. Thebo, A.L.; Drechsel, P.; Lambin, E.; Nelson, K. A global, spatially-explicit assessment of irrigated croplands influenced by urban wastewater flows. Environ. Res. Lett. 2017, 12, 074008. [CrossRef]

28. Spinoni, J.; Naumann, G.; Vogt, J.V. Pan-European seasonal trends and recent changes of drought frequency and severity. Glob. Planet Chang. 2017, 148, 113-130. [CrossRef]

29. Sprenger, C.; Hartog, N.; Hernández, M.; Vilanova, E.; Grützmacher, G.; Scheibler, F.; Hannappel, S. Inventory of managed aquifer recharge sites in Europe: Historical development, current situation and perspectives. Hydrogeol. J. 2017, 25, 1909. [CrossRef]

30. Hamann, E.; Stuyfzand, P.J.; Greskowiak, J.; Timmer, H.; Massmann, G. The fate of organic micropollutants during long-term/long-distance river bank filtration. Sci. Total Environ. 2016, 545, 629-640. [CrossRef] [PubMed]

31. Nham, H.T.; Greskowiak, J.; Nödler, K.; Rahman, M.A.; Spachos, T.; Rusteberg, B.; Massmann, G.; Sauter, M.; Licha, T. Modeling the transport behavior of 16 emerging organic contaminants during soil aquifer treatment. Sci. Total Environ. 2015, 514, 450-458. [CrossRef] [PubMed]

32. World Health Organization (WHO). Guidelines for the Safe Use of Wastewater, Excreta and Greywater; World Health Organization: Geneva, Switzerland, 2006. Available online: https://www.who.int/water_sanitation_ health/publications/gsuweg4/ (accessed on 9 March 2020).

33. Metcalf, L.; Harrison, P.E.; Tchobanoglous, G. Wastewater Engineering: Treatment, Disposal, and Reuse; McGraw-Hill: New York, NY, USA, 2004; Volume 4.

34. Van Wezel, A.P.; Ter Laak, T.L.; Fischer, A.; Bäuerlein, P.S.; Munthe, J.; Posthuma, L. Mitigation options for chemicals of emerging concern in surface waters; operationalising solutions-focused risk assessment. Environ. Sci. Water Res. Technol. 2017, 3, 403-414. [CrossRef]

35. Smeets, P.W.M.H.; Linden, K.; Miehe, U. Rolling literature review on pathogen reduction by water treatment processes. In Proceedings of the 12th IWA International Conference on Water Reclamation and Reuse, Berlin, Germany, 16-20 June 2019.

36. Natural Resource Management Ministerial Council, Environment Protection and Heritage Council, Australian Health Ministers' Conference (NRMMC-EPHC-AHMC). Australian Guidelines for Water Recycling: Managing Health and Environmental Risks: Phase 1. National Water Quality Management Strategy. 2006. Available online: https://www.waterquality.gov.au/guidelines/recycled-water\#managing-health-andenvironmental-risks-phase-1 (accessed on 9 March 2020).

37. Toze, S. PCR and the detection of microbial pathogens in water and wastewater. Water Res. 1999, 33, 3545-3556. [CrossRef]

38. Hijnen, W.A.M.; Medema, G.J. Elimination of Micro-Organisms by Water Treatment Processes; IWA Publishing: London, UK, 2010. 
39. Caicedo, C.; Rosenwinkel, K.H.; Exner, M.; Verstraete, W.; Suchenwirth, R.; Hartemann, P.; Nogueira, R. Legionella occurrence in municipal and industrial wastewater treatment plants and risks of reclaimed wastewater reuse: Review. Water Res. 2019, 149, 21-34. [CrossRef] [PubMed]

40. Garrison, L.E.; Kunz, J.M.; Cooley, L.A.; Moore, M.R.; Lucas, C.; Schrag, S.; Sarisky, J.; Whitney, C.G. Vital Signs: Deficiencies in Environmental Control Identified in Outbreaks of Legionnaires' Disease-North America, 2000-2014. Morb. Mortal. Wkly. Rep. 2016, 65, 576-584. [CrossRef]

41. Van Heijnsbergen, E.; Schalk, J.A.; Euser, S.M.; Brandsema, P.S.; den Boer, J.W.; de Roda Husman, A.M. Confirmed and Potential Sources of Legionella Reviewed. Environ. Sci. Technol. 2015, 49, 4797-4815. [CrossRef]

42. Petzold, M.; Prior, K.; Moran-Gilad, J.; Harmsen, D.; Lück, C. Epidemiological information is key when interpreting whole genome sequence data - lessons learned from a large Legionella pneumophila outbreak in Warstein, Germany, 2013. EuroSurveill 2017, 22. [CrossRef]

43. Van der Kooij, D.; van der Wielen, P.W.J.J. Microbial Growth in Drinking Water Supplies; IWA Publishing: London, UK, 2013.

44. Berendonk, T.U.; Manaia, C.M.; Merlin, C.; Fatta-Kassinos, D.; Cytryn, E.; Walsh, F.; Bürgmann, H.; Sørum, H.; Norström, M.; Pons, M.N.; et al. Tackling antibiotic resistance: The environmental framework. Nat. Rev. Microbiol. 2015, 13, 310-317. [CrossRef]

45. Anderson, M.; Clift, C.; Schulze, K.; Sagan, A.; Nahrgang, S.; Ait Ouakrim, D.; Mossialos, E. Averting the AMR crisis: What are the Avenues for Policy Action for Countries in Europe; Policy Brief, No. 32; European Observatory on Health Systems and Policies: Copenhagen, Denmark, 2019.

46. Christou, A.; Agüera, A.; Bayona, J.M.; Cytryn, E.; Fotopoulos, V.; Lambropoulou, D.; Manaia, C.M.; Michael, C.; Revitt, M.; Schröder, P.; et al. The potential implications of reclaimed wastewater reuse for irrigation on the agricultural environment: The knowns and unknowns of the fate of antibiotics and antibiotic resistant bacteria and resistance genes-A review. Water Res. 2017, 123, 448-467. [CrossRef]

47. Baken, K.A.; Sjerps, R.M.A.; Schriks, M.; van Wezel, A.P. Toxicological risk assessment and prioritization of drinking water relevant contaminants of emerging concern. Environ. Int. 2018, 118, 293-303. [CrossRef]

48. Coppens, L.J.C.; Van Gils, J.; Ter Laak, T.; Raterman, B.; van Wezel, A.P. Towards spatially smart abatement of human pharmaceuticals in surface waters: Defining impact of sewage treatment plants on susceptible functions. Water Res. 2015, 81, 356-365. [CrossRef]

49. Gibson, R.; Durán-Álvarez, J.C.; Estrada, K.L.; Chávez, A.; Jiménez Cisneros, B. Accumulation and leaching potential of some pharmaceuticals and potential endocrine disruptors in soils irrigated with wastewater in the Tula Valley, Mexico. Chemosphere 2010, 81, 1437-1445. [CrossRef] [PubMed]

50. Xu, J.; Wu, L.; Chang, A.C.; Zhang, Y. Impact of long-term reclaimed wastewater irrigation on agricultural soils: A preliminary assessment. J. Hazard. Mater. 2010, 183, 780-786. [CrossRef] [PubMed]

51. Jalali, M.; Merikhpour, H.; Kaledhonkar, M.J.; Van Der Zee, S.E.A.T.M. Effects of wastewater irrigation on soil sodicity and nutrient leaching in calcareous soils. Agric. Water Manag. 2008, 95, 143-153. [CrossRef]

52. Sjerps, R.M.A.; Brunner, A.M.; Fujita, Y.; Bajema, B.; de Jonge, M.; Bäuerlein, P.S.; de Munk, J.; Schriks, M. Clustering and Prioritisation to Design a Risk Based Monitoring Program in Groundwater Sources for Drinking Water. KWR Report. 2018. Available online: https://library.kwrwater.nl/publication/56103342/ (accessed on 9 March 2020).

53. European Commission (EC). Drinking Water Directive in the Directory of European Union consolidated Legislation. 2015. Available online: https:/eur-lex.europa.eu/eli/dir/1998/83/2015-10-27 (accessed on 9 March 2020).

54. Brunner, A.M.; Dingemans, M.M.; Baken, K.A.; van Wezel, A.P. Prioritizing anthropogenic chemicals in drinking water and sources through combined use of mass spectrometry and ToxCast toxicity data. J. Hazard. Mater. 2019, 364, 332-338. [CrossRef] [PubMed]

55. Brack, W.; Ait Aissa, S.; Backhaus, T.; Dulio, V.; Escher, B.I.; Faust, M.; Hilscherova, K.; Hollender, J.; Hollert, H.; Müller, C.; et al. Effect-based methods are key. The European Collaborative Project SOLUTIONS recommends integrating effect-based methods for diagnosis and monitoring of water quality. Environ. Sci. Eur. 2019, 31, 10. [CrossRef]

56. Dingemans, M.M.L.; Baken, K.A.; van der Oost, R.; Schriks, M.; van Wezel, A.P. Risk-based approach in the revised European Union drinking water legislation: Opportunities for bioanalytical tools. Integr. Environ. Assess. Manag. 2019, 15, 126-134. [CrossRef] 
57. Guillossou, R.; Le Roux, J.; Mailler, R.; Vulliet, E.; Morlay, C.; Nauleau, F.; Gasperi, J.; Rocher, V. Organic micropollutants in a large wastewater treatment plant: What are the benefits of an advanced treatment by activated carbon adsorption in comparison to conventional treatment? Chemosphere 2019, 218, 1050-1060. [CrossRef]

58. Krzeminski, P.; Tomei, M.C.; Karaolia, P.; Langenhoff, A.; Almeida, C.M.R.; Felis, E.; Gritten, F.; Andersen, H.R.; Fernandes, T.; Manaia, C.M.; et al. Performance of secondary wastewater treatment methods for the removal of contaminants of emerging concern implicated in crop uptake and antibiotic resistance spread: A review. Sci. Total Environ. 2019, 648, 1052-1081. [CrossRef]

59. Fischer, A.; van Wezel, A.P.; Hollender, J.; Cornelissen, E.; Hofman, R.; van der Hoek, J.P. Development and application of relevance and reliability criteria for water treatment removal efficiencies of chemicals of emerging concern. Water Res. 2019, 161, 274-287. [CrossRef]

60. Ghisi, R.; Vamerali, T.; Manzetti, S. Accumulation of perfluorinated alkyl substances (PFAS) in agricultural plants: A review. Environ. Res. 2019, 169, 326-341. [CrossRef]

61. Voulvoulis, N.; Barceló, D.; Verlicchi, P. Pharmaceutical residues in sewage treatment works and their fate in the receiving environment. Issues Environ. Sci. Technol. 2016, 41, 120-179.

62. Frijns, J.; Smith, H.M.; Brouwer, S.; Garnett, K.; Elelman, R.; Jeffrey, P. How governance regimes shape the implementation of water reuse schemes. Water 2016, 8, 605. [CrossRef]

63. European Food Safety Agency (EFSA). EFSA Guidance Document for Predicting Environmental Concentrations of Active Substances of Plant Protection Products and Transformation Products of These Active Substances in Soil. 2017. Available online: https://efsa.onlinelibrary.wiley.com/doi/abs/10.2903/j.efsa. 2017.4982 (accessed on 9 March 2020).

64. Jeffrey, P.; Fawell, J.; Le Corre, K.; Frijns, J. Applying Regulation to Water Reuse: The Case of the EU. 2017. Available online: http://www.globalwaterforum.org/2017/11/19/applying-regulation-to-water-reuse-thecase-of-the-eu/ (accessed on 9 March 2020).

65. Goodwin, D.; Raffin, M.; Jeffrey, P.; Smith, H.M. Applying the water safety plan to water reuse: Towards a conceptual risk management framework. Environ. Sci. Water Res. Technol. 2015, 1, 709-722. [CrossRef]

66. Binz, C.; Harris-Lovett, S.; Kiparsky, M.; Sedlak, D.L.; Truffer, B. The thorny road to technology legitimation-Institutional work for potable water reuse in California. Technol. Forecast Soc. Chang. 2016, 103, 249-263. [CrossRef]

67. Smith, H.M.; Brouwer, S.; Jeffrey, P.; Frijns, J. Public responses to water reuse-Understanding the evidence. J. Environ. Manag. 2018, 207, 43-50. [CrossRef] [PubMed]

68. Jansen, T.; Claassen, L.; van Kamp, I.; Timmermans, D.R.M. 'All chemical substances are harmful.' public appraisal of uncertain risks of food additives and contaminants. Food Chem. Toxicol. 2020, 136, 110959. [CrossRef]

69. Tahir, S.; Steichen, T.; Shouler, M. Water and Circular Economy: A White Paper. Ellen MacArthur Foundation, Arup, Antea Group. 2018. Available online: https://nextgenwater.eu/wp-content/uploads/2018/10/Water_ and_circular_economy-Co.Project_White_paper.pdf (accessed on 14 April 2020).

70. Smol, M.; Adam, C.; Preisner, M. Circular economy model framework in the European water and wastewater sector. J. Mater. Cycles Waste Manag. 2020, 22, 682-697. [CrossRef]

71. Ayars, J.E.; Christen, E.W.; Hornbuckle, J.W. Controlled drainage for improved water management in arid regions irrigated agriculture. Agric. Water Manag. 2006, 86, 128-139. [CrossRef]

72. Bartholomeus, R.P.; Worm, B.; Oosterhuis, M.; Eertwegh, G.A.P.H.; Raat, K. Reuse of treated wastewater in agriculture? H2O Water Matters 2016, I, 1-6.

(C) 2020 by the authors. Licensee MDPI, Basel, Switzerland. This article is an open access article distributed under the terms and conditions of the Creative Commons Attribution (CC BY) license (http://creativecommons.org/licenses/by/4.0/). 